\title{
RELATIONSHIP BETWEEN NITROGEN SOURCES, GERMINATION AND VIGOR OF SOYBEAN SEEDS ${ }^{1}$
}

\author{
J. MARCOS-FILHO'; C.C. CUSTODIO; G.M.S. CAMARA; E.A. MARCOS; R.E. MIRANDA \\ Departamento de Agricultura, ESALQ/USP, C.P. 9- CEP: 13.418-900 - Piracicaba,SP
}

\begin{abstract}
ARSTRACT: This research was conducted in two experimental areas; the first had been under cultivation with Bradyrhkobium japonicum anually inoculated for several years and the second was cultivated with sugarcane for many years receiving only mineral fertilization. Mineral nitrogen (urea and ammonium) effect was compared with the effects of inoculant treatments (liquid and peat carriers) on plant development, yield and seed quality. After harvesting, seeds were stored under nomal environmental conditions and tested periodically. Germination, accelerated aging, electrical conductivity and seedling emergence tests showed that seeds coming from the area where inoculation was practiced have better quality.Best plant performance regarding plant height at different growth stages and yield was also found in this area. Among the nitrogen sources studied, best results were obtained when peat was the inoculant carrier.
\end{abstract}

Key Words: Glycine max, seeds, inoculation, germination, vigor.

\section{RELAÇŌES ENTRE FONTES DE NITROGENIO, GERMINAÇĀO E VIGOR DE SEMENTES DE SOJA}

RESUMO: A pesquisa foi conduzida em duas áreas experimentais do Departamento de Agricultura, ESALQ/USP. A primeira, cultivada com soja anualmente inoculada com Bradyrhizobium japonicum, durante vários anos e, a segunda, anteriormente cultivada com cana-de-açúcar, recebendo apenas adubação mineral. Os efeitos da aplicação de ureia e de sulfato de amonio foram comparados com os da inoculação de sementes, utilizando-se, produtos veiculados em turfa ou em meio líquido; avaliaram-se o desenvolvimento das plantas, a produção final e a qualidade das sementes (testes de germinação e de vigor) logo ap6s a colheita e durante o armazenamento. Os resultados permitiram constatar 0 melhor desempenho fisiologico das sementes produzidas em area anteriormente cultivada com soja, o mesmo ocorrendo com o desenvolvimento inicial das plantas. Dentre as fontes de nitrogenio avaliadas, a utilização de inoculante veiculado em turfa se mostrou mais favorável.

Deacritores: Glycine max, sementes, inoculação, germinação, vigor.

\section{INTRODUCTION}

Soybean seed inoculation with Bradyrhizobium japonicum has been a routine practice in different producing regions of Brazil. Thus, in addition to the amounts of nitrogen present in the soil, symbiotic fixation contributes significantly to insure the supply of this element, which is necessary for adequate plant development and production. Although the beneficial effects of inoculation are irrefutable, soybean response to the addition of nitrogen fertilizer to the soil and the effects of this procedure are contraditory (GIBSON, 1976; VARGAS, et al; 1982; FLORES et al., 1987).
Several soybean growers and researchers have observed favorable as well unfavorable effects of the application of mineral nitrogen, depending upon the cultivar, quantity and source of nitrogen, sowing date and plant population/area, as well as environmental conditions.

The efficiency of the seed inoculation technique through Bradyrhizobium strains in peat carrier products is recognized in literature. However, even though promising, the information on the effects of the utilization of liquid carriers for the inoculant is less available, as pointed out by HAMMOUD (1981) and DANSO et al. (1990), among others.

\footnotetext{
' Presented at the XXIII International Seed Testing Congress. Buenos Aires, Argentina, 02-04 November, 1992.

2 Bolsista do CNPq.
} 
Soybean response to the application of different sources of nitrogen has been evaluated through parameters such as number and weight of nodules per plant, development of root system, plant height, foliar area, number of pods per plant, yield and weight of seeds. Pratically no references were found on the effects upon physiological quality of the seeds produced; only SMITH \& ELLIS (1980) suggested that soybean nodulation may be influenced by seedling vigor.

It should be pointed out, however, that relationships between nitrogen nutrition, the accumulation of proteins in the seed of other species and its possible influence on physiological quality were observed in studies carried out by CHING \& RYND (1978), BULISANI \& WARNER (1980), HADAVIZADEH \& GEORGE (1988). It is well known that proteins are fundamental components of cell membrane system, whose integrity determines its selective permeability and is directly related with seed performance (BEWLEY \& BLACK, 1985); these authors emphasized the importance of protein reserves for the normal seed metabolic activities by associating them with nucleic acid synthesis, formation of new tissues of the embryonic axis and enzyme activity.

In view of these considerations, the objective of this work was to study the relationships between nitrogen sources, inoculation method, yield and physiological quality of soybean seeds.

\section{MATERIAL AND METHODS}

The research was carried out in two experimental areas, located at Piracicaba, SP, Brazil $\left(22^{\circ} 42^{\prime} 30^{\prime \prime}\right.$ S; $47^{\circ} 38^{\prime} 0^{\prime \prime}$ W; $580 \mathrm{~m}$ altitude).

Area A was under soybean cultivation during $1987 / 88,1988 / 89$ and 1989/90, seed having been inoculated annually with Bractyrhizobium japonicum; Area B had previously been under sugarcane cultivation.

Sowing was done in December 1990, utilizing cultivar IAC-8. A randomized block design with seven treatments, plus control, and five replications, separately for each experimental area, was adopted. The treatments, representing different nitrogen sources, consisted of mineral fertilizers in the form of ammonium sulphate (AS) and urea (U), inoculants carried in mineral oil (MO) or vegetal oil (VO), inoculants carried in peat $\left(\mathbf{P}_{1}\right.$ and $\left.\mathbf{P}_{2}\right)$ and in emulsion (EI).

The plots corresponding to the mineral nitrogen treatments received $10 \mathrm{~kg} / \mathrm{ha}$ of $\mathrm{N}$ at sowing and $50 \mathrm{~kg} / \mathrm{ha}$ of $\mathrm{N}$ during the pre-flowering stage (V12). The inoculation with the products carried in peat was done at the rates of $250 \mathrm{~g}$ and $1000 \mathrm{~g}$ of inoculant per $100 \mathrm{~kg}$ seeds, for areas $\mathrm{A}$ and $B$, respectively. For oily inoculants, 80 and $240 \mathrm{ml}$ of the commercial product $/ 100 \mathrm{~kg}$ of seeds were utilized in areas $\mathbf{A}$ and $\mathbf{B}$, respectively.

Each plot consisted of eight rows, spacing of $60 \mathrm{~cm}$ row width and $5.0 \mathrm{~m}$ row-lenght. All agricultural practices required for an adequate development of the plants, such as herbicide and insecticide applications, phosphate and potassium fertilization and, eventually, irrigation, were used in the experimental areas from the presowing phase on. Determinations consisted of initial stand, plant height at $\mathbf{2 1}$ days after seedling emergence and in the stages corresponding to R1/R2, R5 and R7 (FEHR \& CAVINESS, 1977). After harvesting, the pods were manually shelled, the yield $(\mathrm{kg} / \mathrm{ha})$ and the weight of 1,000 seeds were evaluated, with values corrected for $13 \%$ moisture content. Next, the seeds were stored under room conditions during eight months.

Determinations of moisture content (oven method, $105^{\circ} \mathrm{C}$ for 24 hours), germination and vigor of seeds, were carried out after harvest and every four months. Tests of germination, electric conductivity and accelerated aging were performed according to the International Seed Testing Association Rules (1976) and the Seed Vigor Testing Handbook (ASSOCIATION OF OFFICIAL SEED ANALYSTS, 1983), respectively. Seedling emergence was evaluated 14 days after sowing two samples of 100 seeds for each replication, when seedlings reached the VC stage (FEHR \& CAVINESS, 1977).

\section{RESULTS AND DISCUSSION}

TABLE 1 shows that the initial stand did not present marked variations, considering the effects of the treatments as well as those of experimental areas. The emergence reduction from seeds with emulsion inoculant (EI), even though statistically significant, is not considered sufficient to affect yield,due to the compensation ability presented by soybean plants. 


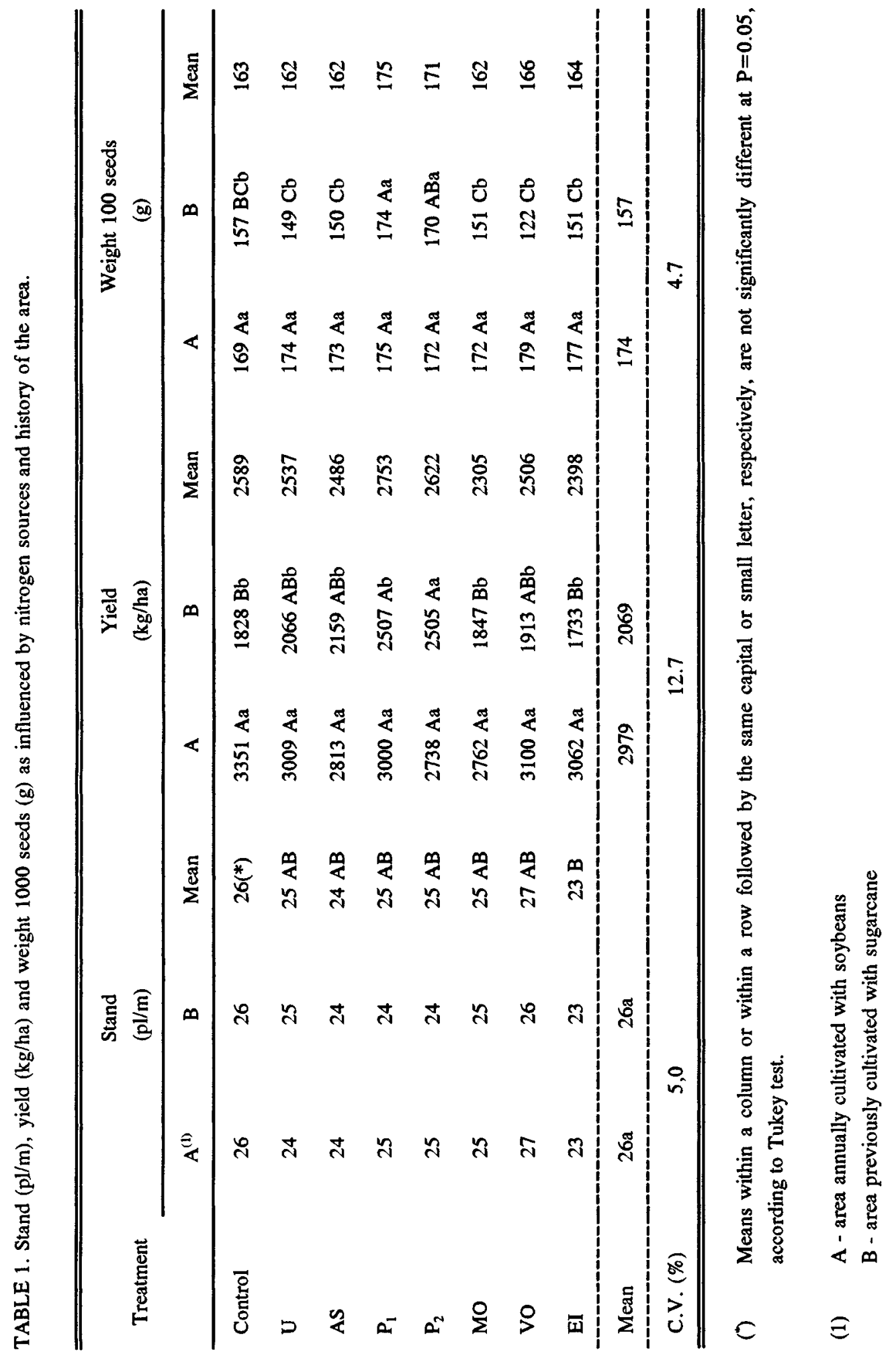




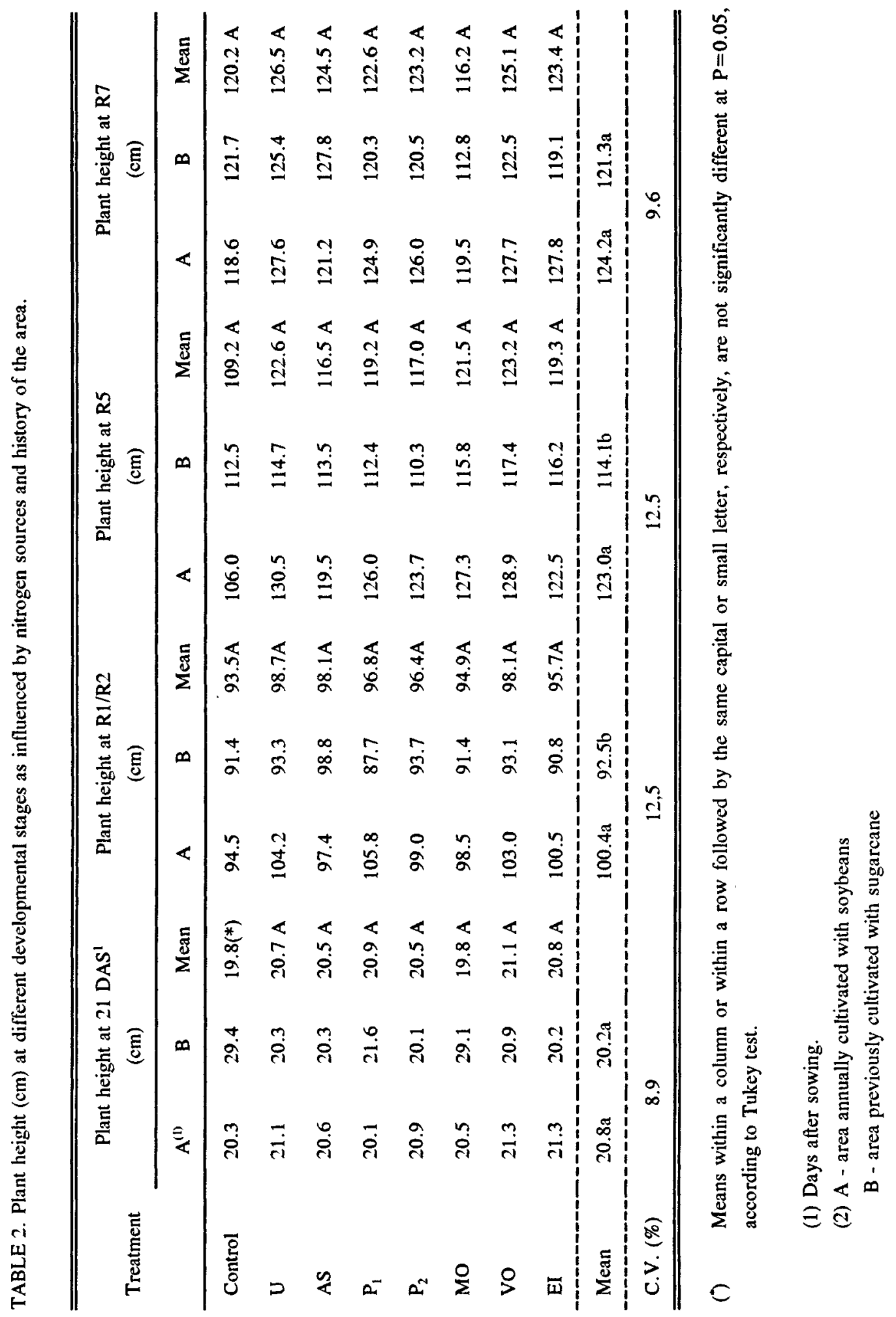


Thus, even in the absence of stand differences, significant effects of treatments were observed on the yield obtained in area $B$, which had not previously been cultivated with soybeans. High performance was noted with the utilization of inoculants carried in peat $\left(\mathbf{P}_{1}\right.$ and $\left.\mathbf{P}_{2}\right)$, while emulsion inoculant (EI), the one carried in mineral oil (MO) and control exhibited lower performance.

It was also shown that soybean yield in area $\mathbf{A}$ was significantly higher than in area $\mathbf{B}$, for all treatments, except for $\mathbf{P}_{\mathbf{2}}$. This superiority was also revealed in the results obtained for weight of 1000 seeds, where, once again, the high performance of treaments $\mathbf{P}_{\mathbf{1}}$ and $\mathbf{P}_{\mathbf{2}}$ was evident.

Therefore, it was observed that annual inoculation presents advantages as compared with cultivation in areas where, in previous years, the crop utilized had received only mineral nutrition; similarly, in this situation, the response to the inoculant carried in peat was shown to be advantageous.

On the other hand, plant height as determined during different stages of development (TABLE 2) showed only marked variations in R1/R2 and in R5, when, although there were no treatment effects, the growth of plants cultivated in area $\mathbf{A}$ was greater. The stages mentioned comprise the period of the greatest photosynthesis activity of soybeans and therefore, these results reinforce advantages of growing soybeans in areas that annually receive inoculated seeds, thus insuring the presence of an adequate concentration of Bradyrhizobium japonicum, in addition to the unquestionable benefits of organic matter. Plant height, dry weight of shoot and roots as well as number of pods/plant of the plants grown in area $\mathbf{A}$ were higher than those of area B (data not presented).

Seed moisture content was shown to be favorable for conservation during the whole storage period, although only data obtained during the testing times are presented in TABLE 3. TABLE 4 shows the data of seed physiological quality, soon after harvest. In general, there were no significant variations between treatments and between areas in germination, accelerated aging and emergence tests, even though the treatments with inoculants carried in peat $\left(\mathbf{P}_{1}\right.$ and $\left.\mathbf{P}_{2}\right)$ tended to show a better performance, mainly in area $B$.

This same tendence remained at four months of storage (TABLE 5), although seed moisture content differences should have contributed for an over estimation of seed performance through the conductivity test for area A (higher moisture content) and through the accelerated aging test for area B (lower M.C.). At eight months of storage, there was no significant decline in germination, as compared with the former period, but the emergence of seedlings was seriously affected by the unfavorable environment (excessive soil moisture). In both tests, the treatments did not differ one from another, however the seeds produced in area $\mathbf{A}$ show better performance than those produced in area $B$. In the accelerated aging test the better quality of the seeds of area $\mathbf{A}$ and the influence of the treatments on the performance of the seeds of area $B$ were confirmed, but the lower values observed for these seeds in the conductivity test, compared with those obtained after four months of storage, remain unexpected.

The results of the electrical conductivity test also showed the consistent superiority of the physiological quality of the seeds produced in area A. They also showed the higher performance of the treatments with inoculants carried in peat, in area B, together with the results of yield, weight 1,000 seeds and plant height in R1/R2 and in R5.

The electrical conductivity test indirectly evaluates seed vigor, reflecting the integrity of the cell membrane system. This test is considered sensitive to relatively small variations in seed vigor and this characteristic was once again verified in this study, when the conductivity results were compared with those of the germination and accelerated aging.

The importance of the protein reserves in seeds, their relationship with the membrane system and metabolic activities were verified by previously mentioned researchers. Therefore it is reasonable to suppose that the utilization of inoculants carried in peat would have favored the development of plants and the production of seeds with higher protein content as compared with the other treatments, specially in soil not previously cultivated with soybeans. This possibility was confirmed by REGITANO-d'ARCE et al. (1992). Chemically analysing the same materials utilized in the present study,these workers found that peat carrier inoculants conducted to the highest protein content seeds, as well as the best quality oil regarding free fatty acids and peroxide values.

Therefore, the results here presented clearly indicate the advantages, in terms of yield and physiological quality, of soybean seed production in soils with a history of inoculation. 


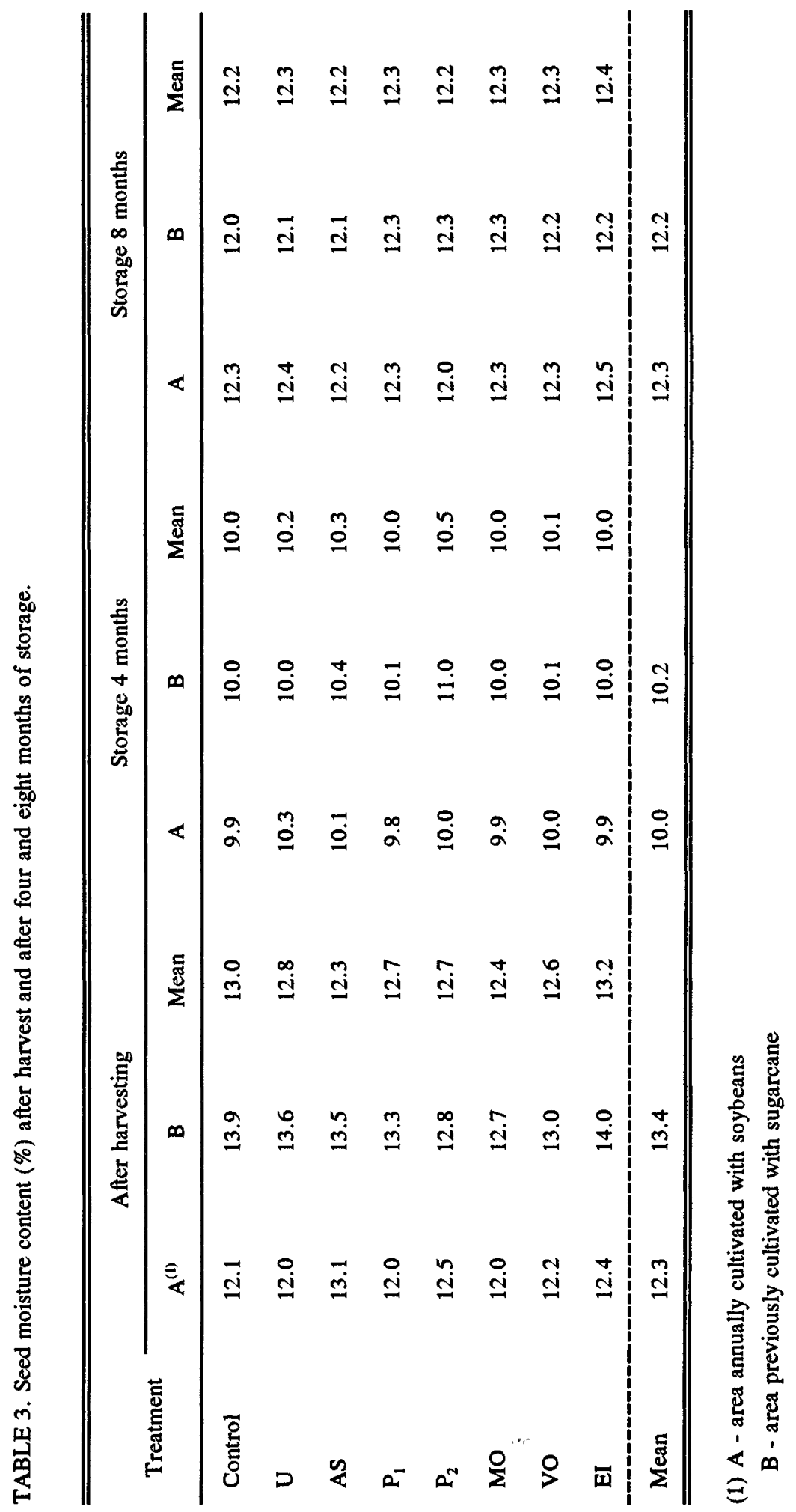




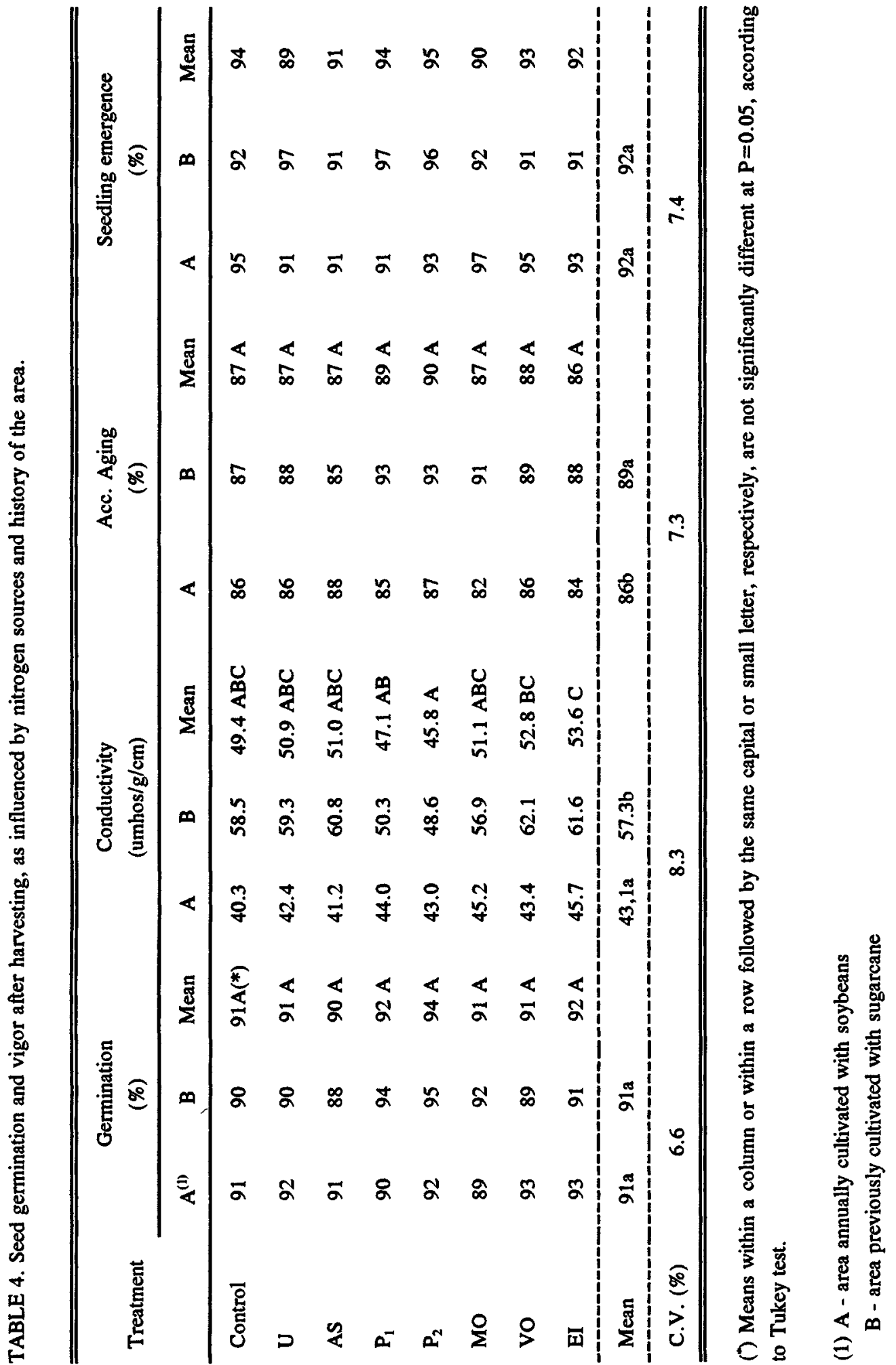




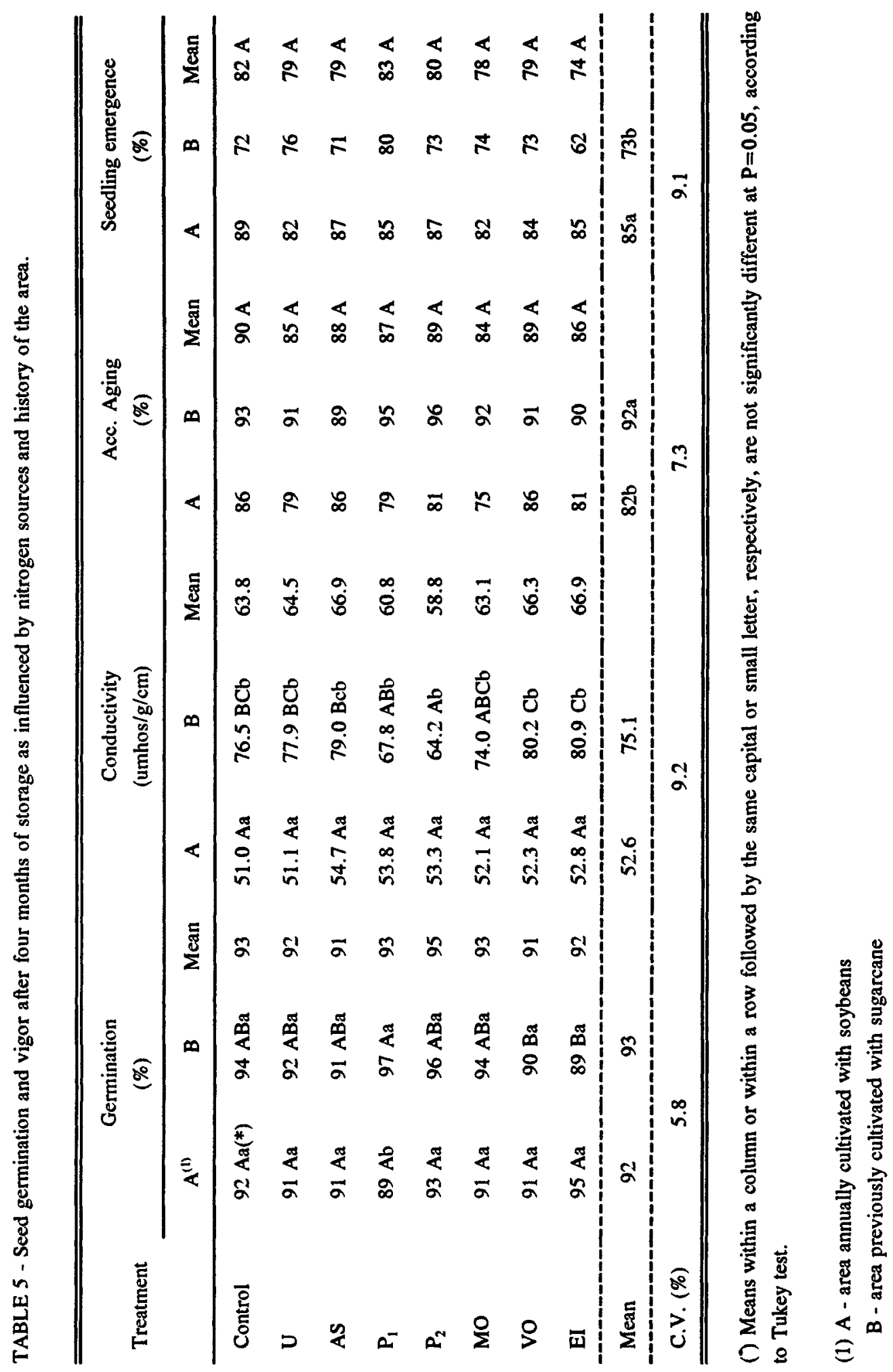




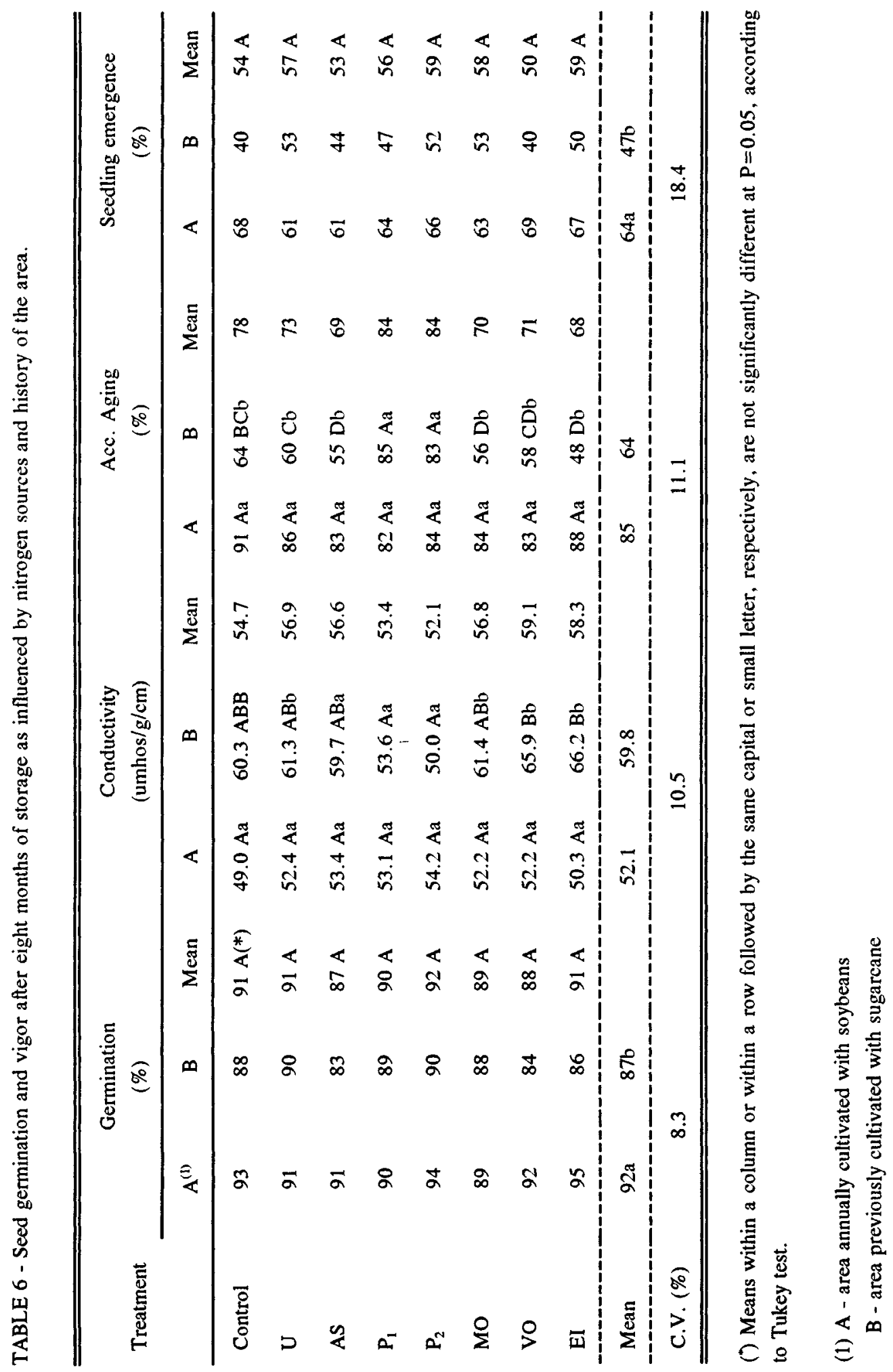


Although the effects of different nitrogen sources have been observed mainly in the area not previously cultivated with soybeans, there were evidences of a higher efficiency of peat as an inoculant carrier and of problems with the utilization of emulsion inoculant.

\section{ACKNOWLEDGEMENTS}

To Fundação de Amparo à Pesquisa do Estado de São Paulo (FAPESP) and Conselho Nacional de Desenvolvimento Científico e Tecnologico ( $\mathrm{CNPq}$ ) for the financial support.

\section{REFERENCES}

ASSOCIATION OF OFFICIAL SEED ANALYSTS. Seed vigor testing handbook. Springfield, 1983, Iv.

BEWLEY, J.D; BLACK, M. Seeds - physiology of development and germination. New York, Plenum Press, 1985. 367p.

BULISANI, E; WARNER, R.L. Seed protein and nitrogen effects upon seedling vigor in wheat. Agronomy Journal, Madison, v.72, p.657-662, 1980.

CHING, T.M.; RYND, L. Developmental differences in embryos of high and low protein wheat seeds during germination. Plant Physiology, Rockville, v.62, p.866-870, 1978.

DANSO, S.K.A.; KAPUYA, J.; HARDARSON, G. Nitrogen fixation and growth of soybean as influenced by varying the methods of inoculation with Bradyrhizobium japonicum. Plant and Soil, The Hague, v.125, p.81-86, 1990.

FEHR, W.R.; CAVINESS, C.E. Stages of soybean development. Ames, lowa State University of Science and Technology. Cooperative Extension Service. 1977. 11p. (Special Report, 80).

FLORES-ROMAN, D.; PALACIOS-MAYORCA, S.; VALLEJO-GOMEZ, E. Efecto de la fertilización y inoculación de soya Var. BM2, con Rhizobium en el rendimiento y calidad de semilla, en condiciones de campo, riego y temporal, bajo el sistema de tres cosechas al año. Revista Latinoamericana de Microbiologia, México, v.25, p.311-320, 1987.
GIBSON, A.H. Limitation to dinitrogen fixation by legumes. In: INTERNATIONAL SYMPOSIUM OF NITROGEN FIXATION, 1., Pullman, 1976. Proceedings... Washington:ISNF, 1976.

HADAVIZADEH, A.; GEORGE, R.A.T. The effect of mother plant nutrition on seed vigor as determined by the seed leachate conductivity in pea, cultivar Sprite. Seed Science and Technology, Zurich, v.16, p.589-599, 1988.

HAMMOUD S.A.Z. Efeito do tratamento de sementes e do tempo de inoculação na nodulação e produção da soja. Pesquisa Agropecuaria Brasileira, Brasília, v.16, p.617-621, 1981.

INTERNATIONAL SEED TESTING ASSOCIATION. International Rules for Seed Testing. Annexes 1976. Seed Science and Technology, Zurich, v.4, p.51-177, 1976.

REGITANO d'ARCE, M.A.B; CARPI, S.M.F.; CAMARA. G.M.S.; MARCOS, E.A. Effects of nitrogen sources on soybean. II. Oil characteristics and seed storability, 1992. Buenos Aires. 23rd ISTA Congress Symposium. Abstracts... Buenos Aires: ISTA. p.94, 1992.

SMITH, R.S.; ELLIS, M.A. Soybean nodulation as influenced by seedling vigor. Agronomy Journal, Madison, v.72, p.605-608, 1980.

VARGAS, M.A.T.; PERES Jr.; R. SUHET, A.R. Adubação nitrogenada, inoculação e épocas de calagem para a soja em um solo sob cerrado. Pesquisa Agropecuária Brasileira, Brasília, v.17, p.1127-1132, 1982.

Enviado para publicação em 13.12.93

Aceito para publicação em 01.02.94 